\title{
COST AND EFFECTIVENESS OF ATYPICAL-ATYPICAL ANTIPSYCHOTIC COMBINATION AND ATYPICAL-TYPICAL ANTIPSYCHOTIC COMBINATION IN PATIENTS OF PSYCHOTIC DISORDERS IN INSTALLATION OF EMERGENCY IN GRHASIA MENTAL HOSPITAL, YOGYAKARTA
}

\author{
Arya Dibyo Adisaputra ${ }^{1,3}$, Endang Darmawan ${ }^{1 *}$, Arum Siwinarni ${ }^{2}$ \\ ${ }^{1}$ Post Graduate Program, Clinical Pharmacy, Ahmad Dahlan University, Jalan Prof. Dr. Soepomo, \\ 55164, Yogyakarta, Indonesia \\ ${ }^{2}$ Mental Grhasia Hospital, Jalan Kaliurang KM.17, 55582, Yogyakarta \\ ${ }^{3}$ Pharmacy Study Program, Mathematics and Natural Science Faculty, Universitas Tadulako
}

Received February 26, 2020; Accepted March 18, 2021

\begin{abstract}
Psychotic disorders create a burden on the government, family, and society because of decreasing patient productivity. The use of atypical-atypical and atypical-typical antipsychotic combinations is one of the most commonly used combinations for patients with psychotic disorders. The study was conducted to determine the average total cost and effectiveness of the therapy measured by the difference in PANSS-EC pre-post scores during intensive care. The study was conducted prospectively to analyse the total cost and effectiveness of the therapy using combinations of antipsychotics in psychotic disorders patients. The measured costs include the cost of nursing classes, laboratory, medical treatment, doctor's visit, and antipsychotic. The effectiveness is measured by the difference in PANSS-EC pre-post scores. As many as 32 treated patients with psychotic disorders met the inclusion criteria. The average cost of atypical-typical antipsychotic combination group (Rp1,184,043) was higher than atypical-atypical antipsychotic combination group (Rp1,115,829). The effectiveness of the therapy was represented by the value of the difference between the PANSS-EC pre and post scores, which in this research yielded a mean of 7,125 for atypical-atypical antipsychotic combinations and 8,375 for atypical-typical antipsychotic combinations. In conclusion, there is a difference in the total average cost and effectiveness of the therapy. There is a difference between PANSS-EC pre and post scores during the time period from intensive room to quiet room in atypical-typical antipsychotic combinations compared with atypical-atypical antipsychotic combinations.
\end{abstract}

Keywords: Psychotic disorders; atypical-atypical antipsychotic combination; atypical-typical antipsychotic combination; cost; effectiveness; PANSS-EC

\section{INTRODUCTION}

Psychotic disorders are associated with impaired emotional, cognitive, and social functions which have the potential to cause long-term disability. Besides, there is also an increasing risk of suicide and harm to others especially when recurrences occur (Starling et al., 2012). The high cases of psychotic disorders throughout the world are of particular concern to stakeholders associated with mental health policies (Kurniawan \& Sulistyarini, 2017).
If the number of people suffering from psychotic disorders increases every year, the treatment or treatment offered is also increasingly diverse, but unfortunately, this does not apply in Indonesia where sufferers of mental health disorders are still considered strange and sufferers should be ostracized (Putri, 2015). The problem of this psychotic disorder causes various kinds of burdens ranging from extraordinary financial burdens, psychological burdens (distress), to social stigma issues.

*Corresponding author: Endang Darmawan

Email: endang.darmawan@pharm.uad.ac.id 
Psychotic disorders create a burden on the government, family, and society because patients' productivity decreases and ultimately imposes a large cost burden for patients and families. Looking at it from a government perspective, this disorder costs a large number of health services. Until now, there are still depletion and mistreatment in patients with severe mental disorders in Indonesia. This is due to inadequate treatment and access to mental health services (Anonymous, 2013).

According to Ranti (2015), there was no difference on the effectiveness of a therapy using combination of haloperidol and risperidone in the treatment of schizophrenia patients during their acute phase based on the PANSS-EC, but haloperidol combination therapy had better cost-effectiveness than risperidone combination therapy. Based on Azani's research (2017) on the analysis of the cost of using antipsychotics, the average total cost of schizophrenia therapy was $\mathrm{Rp}$ $2,558,452$ with the highest average cost namely the atypical-typical antipsychotic combination group $(\operatorname{Rp} 5,170,452)$, the second rank namely groups of atypical antipsychotics ( $R p$ 4,145,912), and the smallest average cost namely the typical antipsychotic group ( $\mathrm{Rp}$ $2,565,440)$.

Realizing that the treatment of psychotic disorders requires a large cost which can reduce the productivity of someone of productive age, researchers are interested in analyzing the cost of therapeutic choices between atypical-atypical antipsychotic combination and atypical-typical antipsychotic combination by looking at their PANSS-EC scores from the intensive room to the quiet room as the indication of therapy effectiveness.

\section{METHODS}

Data were collected prospectively using a cohort design. The inclusion and exclusion criteria in this study are as follows. Inclusion criteria included adult patients aged 18 to 65 years old with a diagnosis of psychotic disorders (without considering the accompanying disease), patients admitted to emergency room with class III category, drug therapy using atypical-atypical antipsychotic combination (as for the combination of drugs used i.e. Clozapine-Risperidone, ClozapineOlanzapine, Risperidone-Quetiapine) and atypical-typical antipsychotics combination (as for the combination of drugs used namely Clozapine-Risperidone-Haloperidol,

Clozapine-Haloperidol, RisperidoneChlorpromazine, Clozapine-RisperidoneTrifluoperazine). Exclusion criteria included patients who went home forcibly, and psychotic disorder patients with incomplete and unclear data.

This study applied a pretest-posttest design to see the PANSS-EC score when patients entered the intensive room until they moved to a quiet room. Analysis of therapeutic effectiveness was assessed using a positive and negative symptom scale on The Positive and Negative Syndrome ScaleExcited Component (PANSS-EC), which is a validated subscale of PANSS used to measure agitation symptoms, and assess five symptoms including poor control of impulses, tension, hostility, cooperation and anxiety (Montoya et al., 2011).

The results of the analysis of direct medical cost data were analyzed using T-test and Mann Whitney test. PANSS-EC pre-post score data results were analyzed using paired T-test and Wilcoxon test.

\section{RESULTS AND DISCUSSION Patient characteristics}

The number of patients who met the inclusion and exclusion criteria was 32 who were then classified into two groups, namely atypical-atypical antipsychotic combination and atypical-typical antipsychotic combination. Characteristics of subjects in this study include gender, age, and level of education.

Patients with psychotic disorders in this study showed that there were more male, as many as 23 patients $(71.88 \%)$, compared to female for as many as nine patients $(28.12 \%)$. This is because women physiologically have estrogen hormone working as dopaminergic which inhibits the release of dopamine in the nucleus accumbent (Khaira et al., 2015). The patients included in this study were adult 
patients aged 18 to 65 years. The average psychotic disorder patients were divided into two based on their age categories namely adulthood of 18 to 40 years by $71.88 \%$ and old age over 40 years by $28.12 \%$.

Psychotic disorders most often occur at the end of adolescence or early adulthood, and rarely occur before adolescence or after the age of 40 years old, because the age range is a productive age that is filled with many triggers of stress and has a large responsibility burden. These stressors include problems with family and coworkers, heavy workload, and economic problems that can affect emotional development (Perwitasari, 2008). The patient characteristic by level of education ranged from secondary education level (high school/ vocational/bachelor) counted for as many as 24 patients $(75 \%)$ to basic education level (primary/junior) counted for as many as eight patients $(25 \%)$.

Therapeutic cost analysis
The cost was calculated using the perspective of the hospital so that the calculated total cost is direct medical costs. Direct medical cost was the fees to be paid as a result of the existence of a disease or during a treatment intervention.

In this study the costs analyzed were direct medical costs including the cost of hospitalization for patients in the intensive care unit until they were transferred to a quiet room, the cost of treatment classes, the cost of medical treatment, the cost of visiting specialist doctors and the cost of antipsychotics.

After statistical analysis, there was no significant difference between the administration of atypical-atypical antipsychotic combination and atypicaltypical antipsychotic combination regarding the cost calculated when the patient was in the intensive room until they entered the quiet room.

Table 1. Direct medical costs for psychotic patients at Grhasia Mental Hospital Yogyakarta

\begin{tabular}{llll}
\hline \multirow{2}{*}{ Direct Medical Cost } & \multicolumn{2}{c}{ Direct Medical Average Costs \pm SD (Rp) } & P (Sig) \\
\cline { 2 - 4 } & Atypical-Atypical Combinations & Atypical-Typical Combinations & \\
\hline Nursing Class Cost & $297.375 \pm 178.018$ & $286.656 \pm 158.747$ & $0,859^{\mathrm{a}}$ \\
\hline Laboratory Cost & $202.156 \pm 41.820$ & $231.813 \pm 37.694$ & $0,029^{\mathrm{b}}$ \\
\hline Medical Action Cost & $485.219 \pm 291.474$ & $490.075 \pm 359.263$ & $0,792^{\mathrm{b}}$ \\
\hline Doctor's Visit Cost & $91.875 \pm 71.013$ & $131.250 \pm 61.954$ & $0,105^{\mathrm{a}}$ \\
\hline Antipsychotic Cost & $39.204 \pm 29.893$ & $44.249 \pm 41.975$ & $0,698^{\mathrm{a}}$ \\
\hline Total & $1.115 .829 \pm 177.270$ & $1.184 .043 \pm 169.466$ & $0,904^{\mathrm{a}}$ \\
\hline \multicolumn{2}{c}{$*=t-t e s t ; b=M a n n$ Whitney } & &
\end{tabular}

*a=t-test; $\mathrm{b}=$ Mann Whitney

The total cost obtained from medical treatment is related to the length of stay in the intensive phase and the frequency of treatment by the relevant medical personnel in the emergency room. The things that must be considered are the general condition of the patients such as their physical examination, and solving complaints experienced by the patient because some patients sometimes get sick and need a treatment other than the treatment for the disease itself (Prawati, 2017).

The length of stay of the patient in the intensive room has a close correlation with the costs to be incurred by the patient because if the patient's condition gets worse, the costs will be incurred even greater. So, patients who enter the intensive room will need a long time until they are moved to a quiet room or rehabilitation room. Room rates for all patients did not differ because in this study all patients were JKN class III psychotic disorders patients. Class III JKN patients were selected so that all patients in the choice of therapy, ward treatment, and doctor's visit had the same costs.

The difference in the cost of the specialist doctor's visit is due to the difference in the severity of each patient condition in which there are patients who have repeatedly been admitted to care (relapsed) and patients who are first entering the treatment room. Treatment using antipsychotics is the main therapy for patients with psychotic disorders. 
The selection of antipsychotics shoul consider the clinical signs of the patient, th efficacy profile and the side effects of the drug used. The type of antipsychotic given to a patien depends on the patient's response to the dru: (Fahrul, 2014). This supports another researc report which states that many patients experienc relapses due to the lack of funds to pay for drug after being released from a mental hospita patient non-compliance with treatment, an abusive treatment by family and surroundin: communities (Amelia, 2013).

\section{PANSS-EC}

PANSS-EC is an instrument used to assess positive and negative symptoms of psychotic disorder patients. PANSS-EC score measurements are performed when the patient first arrives in the intensive room and remeasured when the patient is moved to a quiet room. The PANSS-EC score assessment is performed by a psychiatrist. The following are the PANSS-EC pre-post scores:

Table 2. Calculation results of the average pre (intensive care) - post (quiet room) PANSS-EC scores on psychotic disorder patientsat Grhasia Mental Hospital

\begin{tabular}{ccc}
\hline \multirow{2}{*}{ Group } & \multicolumn{2}{c}{ Average PANSS-EC Score } \\
\cline { 2 - 3 } & PRE & POST \\
\hline Atypical-Atypical Combination & 19,68 & 12,56 \\
\hline Atypical-Typical Combination & 19,56 & 11,18 \\
\hline
\end{tabular}

Table 3. Calculation results of the average difference on pre (intensive care) - post (quiet room) PANSS-EC scores on psychotic disorder patients at Grhasia Mental Hospital

\begin{tabular}{ccc}
\hline Group & $\begin{array}{c}\text { Average Difference in PANSS-EC Pre and } \\
\text { Post Scores } \pm \text { SD }\end{array}$ & P (sig) \\
\hline Atypical-Atypical Combination & $7,125 \pm 3,222$ & 0,001 \\
\hline Atypical-Typical Combination & $8,375 \pm 2,390$ & 0,001 \\
\hline
\end{tabular}

The decrease in the severity of psychotic disorder patients is seen based on the difference between PAN and pre-post PANSSEC scores. Statistical data shows that the probability value is 0.001 , so it can be said that the average difference between pre and post PANSS-EC scores in the two antipsychotic therapy groups is significant in terms of severity decrease in schizophrenia patients due to differences in antipsychotic use patterns. In addition, based on the data in this study, all patterns of antipsychotic use given to patients with psychotic disorders resulted in a decrease in PANSS-EC scores. This explains that the pattern of antipsychotic use is related to and influences the decrease in severity (Purwandityo, 2018).

According to Ranti (2015), there was no difference in the effectiveness of a therapy using the combination of haloperidol and risperidone in the acute phase of schizophrenic patients based on PANSS-EC values. Combination of risperidone was more cost- effective and reduced PANSS compared to haloperidol combination, making risperidone combination to be the dominant therapeutic choice in the treatment of patients with schizophrenia in the mental hospital of Prof. Dr. Rasumbuysang, North Sulawesi Province (Karaeng, 2018).

Correl et al. (2009) and Haw et al. (2003) affirm that in certain clinical conditions, the antipsychotic combination can be better than monotherapy. This can be seen based on the patient's PANSS score decrease. The lack of efficacy of monotherapy is the main reason for starting and continuing with a combination of antipsychotics. It appears that positive symptoms and behavioral disorders of schizophrenic patients decrease more.

\section{CONCLUSION}

Although there was a difference in the average total cost between atypical-typical antipsychotics combination and atypicalatypical antipsychotics combination, the 
difference was not statistically significant $(\mathrm{p}>$ 0.05). Regarding the effectiveness of the therapy, there was a difference between pre and post PANSS-EC scores in typical-atypical and atypical-atypical antipsychotics combination applied for patients in intensive care to be moved to a quiet room.

\section{ETHICAL APPROVAL}

This study was approved by the Ethical Health Research Committee of the Ghrasia Mental Hospital under number 12/ECKEPKRSJG/VIII/2019.

\section{REFERENCES}

Amelia, D. R. \& Anwar, Z., 2013. Relaps Pada Pasien Skizofrenia. Jurnal Ilmiah Psikologi Terapan, 1(1), 53-65.

Anonim, 2013. Riset Kesehatan Dasar. Badan Penelitian dan Pengembangan Kesehatan Kementerian Republik Indonesia tahun 2013. Jakarta.

Azani, E., Analisis Biaya Dan Outcome Terapi Penggunaan Antipsikotika Pada Pasien Rawat Inap Skizofrenia RSJD Surakarta Tahun 2017, Tesis, Program Studi S2 Ilmu Farmasi Fakultas Farmasi Universitas Setia Budi, Surakarta.

Correll CU., Rummel-Kluge C., CorvesC., Kane JM., Leucht S., 2009. Antipsychotic Combination vs Monotherapy in Schizophrenia: A Meta Analysis of RCT. Schizophr Bull, 32(2), 443-57.

Dongoran S. F., 2014. Gambaran Karakteristik Pasien Skizofrenia di Rumah Sakit Jiwa Daerah Provinsi Sumatera Utara Medan. Skripsi. Fakultas Keperawatan Universitas Sumatera Utara.

Fahrul, Mukaddas, A., \& Faustine, I., 2014. 2 Prodi Farmasi, untad Lab. Farmakologi dan Farmasi Klinik, Prodi Farmasi, Untad 1. Online Jurnal of Natural Science, 3(1), 40-46.

Fujimaki K., Takahashi T., Morinobu S., 2012. Association of Typical versus Atypical Antipsychotics with Symptoms and Quality of Life in Schizophrenia. PLoS One, 7(5), e37087. DOI: 10.1371/ journal.pone.0037087

Haw C, Stubbs J., 2003. Combined Antipsychotics for 'Difficult-tomanage' and Forensic Patients with Schizophrenia: Reasons for Prescribing and Perceived Benefits. Psychiatr Bull, 27(12), 449-52.

Idaiani, S., Yunita, I., Tjandrarini, D. H., Indrawati, L., Darmayanti, I., Kusumawardani, N., \&Mubasyiroh, R., 2019. Prevalensi Psikosis di Indonesia Berdasarkan Lie Kesehatan Dasar The Prevalence of Psychosis in Indonesia Based on Basic Health Research. Jurnal Penelitian Dan Pengembangan Pelayanan Kesehatan, 3(1), 9-16.

Ising, H. K., Lokkerbol, J., Rietdijk, J., Dragt, S., Klaassen, R. M. C., Kraan, T., ... van der Gaag, M., 2017. Four-Year Cost-effectiveness of Cognitive Behavior Therapy for Preventing Firstepisode Psychosis: The Dutch Early Detection Intervention Evaluation (EDIE-NL) Trial. Schizophrenia Bulletin, 43(2), 365-374.

Kaplan H.I., Sadock B.J., Greb Jack., 2010. Sinopsis Psikiatri. Jilid Satu. Binarupa Aksara.

Karaeng, Nety Daud, et al., 2019. "Analisis Efektivitas Biaya Penggunaan Risperidone Kombinasi Dan Haloperidol Kombinasi Pada Pasien Skizofrenia Di Rsj. Dr. V. L. Ratumbuysang Provinsi Sulawesi Utara." Majalah Farmasi Dan Farmakologi, 22(3), 69.

Khaira, N.R., A. Nugroho., A. Saputra, 2015. Drug Related Problems AntiPsikotik pada Pasien Skizofrenia Paranoid Akut di RS Jiwa X Jakarta. Farmasains, 2, 275-280.

Kurniawan, Y., \&Sulistyarini, I., 2017. Komunitas Sehati (Sehat Jiwa dan Hati) Sebagai Intervensi Kesehatan Mental Berbasis Masyarakat. INSAN Jurnal Psikologi Dan Kesehatan Mental, 1(2), 112.

Perwitasari, D. A., 2008. Kajian penggunaan atypical antipsychotic dan conventional antipsdychotic pada pasien skizofrenia 
di rumah sakit Grhasia Yogyakarta. Prosiding. ISBN: 978-979-17547-0-5.

Prawati, N. L. A. G., 2017. Analisis Efektivitas Biaya Penggunaan Kombinasi Antipsikotik Tipikal Dibandingkan dengan Kombinasi Antipsikotik Tipikal dan Atipikal pada Pasien Skizofrenia Rawat Inap di RSJD Surakarta pada Tahun 2016. Skripsi. Universitas Setia Budi.

Purwandityo, G. A., Febrianti, Y., Sari, P. C., 2018. Pengaruh Antipsikotik terhadap Penurunan Skor The Positive and Negative Syndrome Scale-Excited Component, Jurnal Farmasi Klinik Indonesia, 7(1), 19-29.

Ranti, I., Octaviany, A. F., \&Kinanti, S., 2015. Analisis Efektivitas Terapi dan Biaya antara Haloperidol Kombinasi dengan Risperidon Kombinasi pada Terapi
Skizofrenia Fase Akut Analysis Therapeutic and Cost Effectiveness of Combination Therapy between Risperidone and Haloperidol on Acute Phase of Schiz. Mutiara Medika, 15(1), 57-64.

Riset Kesehatan Dasar (Riskesdas), 2013. Badan Penelitian dan Pengembangan Kesehatan Kementerian RI tahun 2013. Rubio-Abadal, E., Usall, J., Barajas, A., Carlson, J., Iniesta, R., Huerta-Ramos, E., ... Villalta, V., 2016. Relationship between Menarche and Psychosis Onset in Women with First Episode of Psychosis. Early Intervention in Psychiatry, 10(5), 419-425.

Starling, J., Feijo, I., \&Franzcp, J. S., 2012. Psychotic Disorders of Early Onset. IACAPAP E-Textbook of Child and Adolescent Mental Health, 1-22. 